\title{
EFFECT OF THE CABERGOLINE IN IMPLANTATION WHEN ADMINISTERED TO PREVENT OVARIAN HYPERSTIMULATION SYNDROME
}

\author{
By \\ Marwa S. Al-Gendy, Yehia A. Wafa and Hesham F. Abo-Sena \\ Department of Obstetrics \& Gynecology, Faculty of Medicine, Al-Azhar University \\ Corresponding author: Marwa Shawky Al-Gendy; \\ E-mail: dr.marwashawky@gmail.com
}

\begin{abstract}
Background: Ovarian hyper stimulation syndrome (OHSS) is an iatrogenic and potentially life-threatening disease process, which may occur in healthy young women undergoing control ovarian hyper stimulation.

Objective: To assess the effect of Cabergoline on implantation when used to prevent or treat ovarian hyper stimulation syndrome.

Patients and Methods: This study was conducted at IVF Unit, Al-Hussein Hospital, Al-Azhar University from March 2015 to March 2020 on 100 women with high risk evidence to ovarian hyper stimulation syndrome with ovulation induction divided in two equal groups: Group I: 50 started on tablet cabergoline 0.5 $\mathrm{mg} /$ day from the day of ovulation trigger and continued until the next 8 days and Group II: 50 did not take cabergoline. This study was carried on private center. All of the patients were followed up by pregnancy test in serum (BHCG titre) and examination by transvaginal U/S at 6 week of gestation.
\end{abstract}

Results: The study showed no statistically significant difference between Group I and Group II: to primary or secondary infertility. However, there was a statistically significant increase on positive group I compared to group II according to fetal heart pulsation.

Conclusion: Cabergoline reduced the incidence of OHSS in ICSI cycles. In women at high risk of OHSS, cabergoline can be administered as soon as the hCG injection to prevent early OHSS. Higher rates of clinical and chemical pregnancy were observed after cabergoline administration in ICSI cycles.

Key words: cabergoline, implantation, ovarian hyper stimulation syndrome.

\section{INTRODUCTION}

Ovarian hyper stimulation syndrome (OHSS) is an iatrogenic and potentially life-threatening disease process, which may occur in healthy young women undergoing control ovarian hyper stimulation for assisted reproduction. As the treatment is largely empirical, prevention forms the mainstay of management (Busso et al., 2010).
Severe forms of ovarian hyper stimulation syndrome (OHSS) arise in $0.5-5 \%$ of assisted reproduction treatment (ART) cycles (Devroey and Adriaensen, 2011).

Type 2 receptors for vascular endothelial growth factor are believed to be involved in the pathophysiology of ovarian hyper stimulation syndrome (OHSS). Only women of childbearing age 
are affected by ovarian hyper stimulation syndrome. Women of young age, as well as those with low body weight, polycystic ovarian syndrome, or previous episodes of hyper stimulation are all at increased risk for developing OHSS. In addition, an increased number of small and mediumsized follicles and elevated estradiol levels around the assumed time of ovulation increase the incidence (Várnagy et al., 2009).

Ovarian hyper stimulation syndrome (OHSS) occurs when ovaries primed with follicle-stimulating hormone (FSH)/ leuteinizing hormone (LH) are subsequently exposed to human chorionic gonadotropin (hCG) (Gómez et al., 2010).

The ultimate pathophysiological step underlying this clinical picture is increased vascular permeability (VP). With the administration of hCG, the expression vascular endothelial growth factor (VEGF) and VEGF receptor 2 (VEGFR-2) mRNA increases significantly rising to a maximum coinciding with peaked VP. Immunohistochemistry shows the presence of VEGF and VEGFR-2 proteins in the granulosa-lutein and endothelial cells of the entire corpus luteum. These findings suggest that the syndrome can be prevented by inducing ovulation with LH or gonadotropinreleasing hormone analogs, which prevent VEGF overexpression. Also, Coad ministration of a dopamine agonist inhibits phosphorylation of the receptor VEGFR-2. In conclusion, the pathophysiological mechanisms involved in OHSS show that targeting VEGF/VEGFR2 is an effective preventive approach to treat the syndrome. Pharmaco-prevention through dopamine agonists is effective only in nonpregnant high-risk OHSS women. Embryo cryopreservation plus dopamine agonist administration might be the most appropriate way to prevent OHSS in highrisk patients (Gómez et al., 2010).

The development of OHSS after controlled ovarian hyper- stimulation with gonadotropins requires the administration of human chorionic gonadotropin (hCG) because the syndrome does not develop if hCG is withheld (Tang et al., 2012).

Because hCG has no vasoactive activity, the angiogenic molecule vascular endothelial growth factor (VEGF) is the most important mediator of hCGdependent ovarian angiogenesis. It is known that VEGF is expressed in human ovaries and that VEGF mRNA levels increase after hCG administration in granulosa cells (Chen et al., 2010).

Cabergoline, a dopamine receptor-2 agonist used in the treatment of human hyper-prolactinaemia, is proposed to prevent OHSS in ovarian stimulation through inhibition of the phosphorylation ofVEGFR-2 (Soares, 2012).

The present work aimed to evaluate the effect of Cabergoline on implantation when used to prevent or treat ovarian hyper stimulation syndrome.

\section{PATIENTS AND METHODS}

A written informed consent was taken from every participant after proper explanation of the study.

The current prospective observational control study was conducted on 100 cases according to sample formula in a role of randomization of women undergoing 
assisted reproduction treatment by computer program.

This study was carried out at IVF Unit, Al-Hussein Hospital, Al-Azhar University from March 2015 to March 2020. This study was conducted on women with high risk evidence to ovarian hyperstimulation syndrome divided in two equal groups: Group I started on tablet cabergoline ( 0.5 $\mathrm{mg}$ /day) from the day of ovulation trigger and continued for the next 8 days and Group II where cabergoline was not taken.

All patients were on long protocol starting gonadotropin releasing hormone analogue ( $\mathrm{Gn} \mathrm{Rh}$ ) on midluteal phase of the proceeding menstrual cycle. After confirmation of down regulation (basal E2level > $35 \mathrm{pg} / \mathrm{ml}$.), ovulation induction started using human menopausal gonadotropin 3 ampoule per day, and the dose was adjusted according to response. When 3 or more leading follicles reaching 18-20 mms, $10000 \mathrm{IU}$ of hCG was given, oocyte retrieval was done 34 hours later. Ultrasound guided intrauterine embryo transfer (ET) of 2 embryos was done after 48 hours. The duration of this study was 4 years.

The study included patients with primary or secondary infertility, evidence of high risk for development ovarian hyper stimulation syndrome: Patients with PCOS, E2 level, on day of hCG injection, $>2500$ picogram permilliliter $(\mathrm{pg} / \mathrm{ml})$, More than 20 follicles > 12 millimeter (mm) on the 10thof the cycle, Obese women with high BMI.

Patients with sensitivity to cabergoline, high FSH $>12 \mathrm{IU}$, low $\mathrm{AMH}<0.1 \mathrm{ng} / \mathrm{ml}$, pelvic pathology away from polycystic ovary and uterine factor affect implantation eg. Uterine myoma, uterine septum and uterine polyp were excluded from the study.

All females were assessed by the following: Complete history taking: age, cycle regulatory, General examination: BMI, Local examination, Investigations:, a. Routine: CBC.

b. Hormonal: FSH, LH, Prolactin (PL), TSH and E2 level.

All previous hormones were tested in day 2 or day 3 of cycle:

- $\beta$ Subunit of Human chorionic gonadotropin was done

- 15 days post hCG injection.

c. Other investigations according to case condition and degree of ovarian hyper stimulation syndrome: WBCs, serum creatinine.

Imaging: Serial transvaginal sonography was performed until peak offollicular maturation (when 3 or more leading follicles reaching $18-20 \mathrm{mms}$,) was observed, Transvaginal and / or abdominal sonography for detection of: Number of follicles on day of hCG administration, Assessment of mean ovarian volume by 2D ultrasound; free fluid in Douglas pouch on day of ET, Presence of fetal heart pulsation 2 weeks after a positive pregnancy test by Mindray DC 70 ultrasound.

Classification of OHSS was done according to the higher criteria of description of OHSS: Mild, Moderate, Severe and Critical.

\section{Statistical analysis:}

Recorded data were analyzed using the statistical package for the social sciences, version 20.0 (SPSS Inc., Chicago, Illinois, 
USA). Quantitative data were expressed as mean \pm standard deviation (SD). Qualitative data were expressed as frequency and percentage. The following tests were done: Independent-samples ttest of significance was used when comparing between two means in parametric distribution.
Mann Whitney $U$ test was used for twogroup comparisons in non-parametric data. Chi-square (x2) test of significance was used in order to compare proportions between qualitative parameters.

P-value $<\mathbf{0 . 0 5}$ was considered significant.

\section{RESULTS}

There was statistically significant difference between Group I: Cabergoline and Group II: Control according to OHSS, while age (years), BMI, and Primary or secondary infertility insignificant. (Table 1).

Table (1): Comparison between Group I: Cabergoline and Group II: Control according to age (years)

\begin{tabular}{|c|c|c|c|}
\hline Parameters $\quad$ Groups & $\begin{array}{c}\text { Group I: Cabergoline } \\
(n=50)\end{array}$ & $\begin{array}{c}\text { Group II: Control } \\
(n=50)\end{array}$ & p-value \\
\hline \multicolumn{4}{|l|}{ Age $(\text { years })^{(\#)}$} \\
\hline Mean \pm SD & $29.72 \pm 5.93$ & $29.48 \pm 6.04$ & \multirow{2}{*}{0.841} \\
\hline Range & $18-42$ & $20-43$ & \\
\hline \multicolumn{4}{|l|}{ BMI $^{(\#)}$} \\
\hline Mean \pm SD & $26.27 \pm 4.99$ & $25.74 \pm 4.94$ & \multirow{2}{*}{0.595} \\
\hline Range & $22-29$ & $22-28.5$ & \\
\hline \multicolumn{4}{|l|}{ OHSS $^{(\S)}$} \\
\hline No & $45(90.0 \%)$ & $37(74.0 \%)$ & \multirow{5}{*}{0.038} \\
\hline Yes & $5(10.0 \%)$ & $13(26.0 \%)$ & \\
\hline Mild & $3(6.0 \%)$ & $5(10.0 \%)$ & \\
\hline Moderate & $1(2.0 \%)$ & $6(12.0 \%)$ & \\
\hline Severe & $1(2.0 \%)$ & $2(4.0 \%)$ & \\
\hline \multicolumn{4}{|l|}{ Primary or secondary infertility ${ }^{(\S)}$} \\
\hline Primary & $27(54.0 \%)$ & $23(46.0 \%)$ & \multirow{2}{*}{0.424} \\
\hline Secondary & $23(46.0 \%)$ & $27(54.0 \%)$ & \\
\hline
\end{tabular}

Using: (§)Chi-square test; (\#)Independent Sample t-test 
There were statistically significant differences between Group I: Cabergoline and Group II: Control according to HCG and fetal heart pulsation, while FSH, AMH, E2, Ovarian volume, AFC, Number of gonadotropin ampoules and Duration of stimulation (days) insignificant. (Table 2).

Table (2): Comparison between Group I: Cabergoline and Group II: Control according to hormones

\begin{tabular}{|c|c|c|c|}
\hline Hormones & $\begin{array}{c}\text { Group I: Cabergoline } \\
(n=50)\end{array}$ & $\begin{array}{l}\text { Group II: Control } \\
(n=50)\end{array}$ & p-value \\
\hline \multicolumn{4}{|l|}{ FSH $^{(*)}$} \\
\hline Mean \pm SD & Median [14, IQR 10] & Median [11, IQR 8] & \multirow{2}{*}{0.381} \\
\hline Range & $1.2-84$ & $3.5-89$ & \\
\hline \multicolumn{4}{|l|}{$\mathbf{A M H}^{(\ddagger)}$} \\
\hline Mean \pm SD & Median [5, IQR 3] & Median [3, IQR 3] & \multirow{2}{*}{0.238} \\
\hline Range & $0.3-63$ & $0.3-51$ & \\
\hline \multicolumn{4}{|l|}{$\mathbf{E 2} 2^{(\#)}$} \\
\hline Mean \pm SD & $4783.6 \pm 920.8$ & $4800.2 \pm 815.9$ & 0.924 \\
\hline Ovarian volume (ml) ${ }^{(\#)}$ & $135.12 \pm 67.90$ & $140.46 \pm 54.90$ & 0.295 \\
\hline \multicolumn{4}{|l|}{$\mathbf{A F C}^{(\#)}$} \\
\hline Range & $3-10$ & $4-13$ & \multirow{2}{*}{0.138} \\
\hline Mean $\pm S D$ & $7.15 \pm 2.02$ & $8.50 \pm 2.64$ & \\
\hline $\begin{array}{l}\text { Number of gonadotropin } \\
\text { ampoules (75 IU/ampoule) }\end{array}$ & Median [29, IQR 12] & [30, IQR 13] & 0.536 \\
\hline Duration of stimulation (days) ${ }^{(\ddagger)}$ & Median [9, IQR 2] & Median [9, IQR 3] & 0.691 \\
\hline \multicolumn{4}{|l|}{$\mathbf{H C G}^{(\S)}$} \\
\hline Negative & $9(18.4 \%)$ & $26(54.17 \%)$ & \multirow{2}{*}{$<0.001$} \\
\hline Positive & $40(81.6 \%)$ & $22(45.8 \%)$ & \\
\hline Chemical pregnancy & $7 / 40(17.5 \%)$ & $3 / 22(13.6 \%)$ & \\
\hline Clinical pregnancy & $33 / 40(82.5 \%)$ & $19 / 22(86.4 \%)$ & \\
\hline \multicolumn{4}{|l|}{ Fetal heart pulsation ${ }^{(\S)}$} \\
\hline Negative & $11(27.5 \%)$ & $12(54.5 \%)$ & \multirow{2}{*}{0.035} \\
\hline Positive & $29(72.5 \%)$ & $10(45.5 \%)$ & \\
\hline
\end{tabular}

Using: (§)Chi-square test; (\#)Independent Sample t-test; (†) Mann-Whitney test

\section{DISCUSSION}

Ovarian hyper stimulation syndrome, primarily a systemic disease results from vasoactive products released by the ovaries hyper stimulated with gonadotropins. It is more frequently seen when a strong ovarian response occurs, characterized by the development of a large number of follicles, high E2 values, and enlarged ovaries. Of the various pathophysiological mechanisms implicated for the causation of OHSS, it is the angiogenic molecule, VEGF, which has been found to be the biggest mediator of this potentially dreadful complication. It has been proven that VEGF stimulates new blood vessel development and vascular hyper-permeability by interacting with its VEGFR2 (Chen et al., 2013).

This study explored the influence on final oocyte maturation of different 
starting times of cabergoline therapy to prevent OHSS which is a serious problem for specialists dealing with infertility ( $L O$ Monte et al., 2013).

Cabergoline, a dopamine agonist inhibiting VEGFR-2 phosphorylation and signaling, effectively reduced the incidence of OHSS and cycle cancellation without any adverse effects on pregnancy. The findings of the present study were in agreement with those of previous studies. Ovarian hyper stimulation syndrome, as a potentially life-threatening situation and the most serious complication of assisted reproduction treatment, is regarded as an iatrogenic complication which must be avoided, and in case of occurrence its severity must be reduced. Considering the physical and psychological consequences along with medical costs like hospitalization, every intervention to decrease VEGF expression or antagonizing its effects would be valuable (Mourad et al., 2017).

By using Cabergoline in a placebocontrolled study with the aim of preventing OHSS, we have demonstrated, for the first time, that this $\mathrm{Dp}$ agonist blocks the increment in hemoconcentration and VP due to hCG, evident when magnetic resonance was employed 5 days after its administration, thereby reducing the incidence of moderate OHSS.

The action of Cabergoline on the ovaries seems to be mediated through activation of Dp-r2, because endogenous PRL secretion, a marker of Dp-r2 activity, was consistently reduced by the administration of said agonist. The presence of Dp-r2 in human granulosaluteal cells was confirmed by two different molecular methods. To our knowledge, this is the first report that describes Dp-r2 in human ovarian cells. Moreover, quantification of Dp-r2 mRNA expression showed variations among patients that may explain, at least in part, any variations in responses to Dp agonists in subsequent clinical trials (Kamel et al., 2016).

There was no significant difference between the studied groups regarding age, duration of infertility, In this study, there was significant difference between the studied groups according to chemical and clinical pregnancy rates. This mismatched with the result of El-Garhy et al. (2018) who has evaluated the effect of cabergoline treatment on preventing OHSS in 35 women at a high risk of developing OHSS and who received cabergoline compared with high risk controls who did not receive cabergoline. Implantation rates were comparable between the groups.

The result disagreed with the result of Jellad Set al. (2017) who reported that there was no evidence of statistically significant differences in live birth rate, ongoing pregnancy rate, clinical pregnancy rate and miscarriage rate in patients who received cabergoline compared with high risk controls who did not receive cabergoline.

Our study agreed with the results of Seow et al. (2013), where oral cabergoline ( $0.5 \mathrm{mg}$ daily) was given as an intervention and compared with a matched placebo. A statistically significant reduction in OHSS was observed in the cabergoline-treated group. There was a statistically significant difference in the incidence of moderate OHSS, favoring cabergoline but not in 
severe OHSS. There was no significant difference in the clinical pregnancy rate or miscarriage rate. However, no data on multiple pregnancy rate or live birth rate were reported in either trial. They concluded that cabergoline appears to reduce the risk of OHSS in high-risk women, especially for moderate OHSS. The use of cabergoline did not affect the pregnancy outcome (clinical pregnancy rate or miscarriage rate), nor was there an increased risk of adverse events. Our study results agreed with the result of Chen et al. (2013), who showed that cabergoline reduces the incidence of OHSS and the risk of hospitalization due to the lower occurrence of OHSS.

This study agreed with the result of Leitao et al. (2014), who showed no OHSS in the cabergoline group (0\%), whereas there were two OHSS $(3.6 \%)$ in the coasting group. However, this difference was not significant. They concluded that $0.5 \mathrm{mg}$ daily use of cabergoline for 8 days beginning from hCG administration is a very effective way to reduce moderate-severe OHSS without sacrificing pregnancy rates in patients at risk of developing OHSS.

In this study, there was significant difference between the studied groups according to incidence of OHSS in $13.3 \%$ cases, $10 \%$ mild OHSS, and $3.3 \%$ moderate OHSS, in cabergoline group and $43.3 \%$ of cases, $30 \%$ mild OHSS, and $13.3 \%$ moderate OHSS, in control group. This matched with the result of Gaafar et al (2019), who presented a well-designed randomized double-blind study that investigated the role of cabergoline on the prevention of OHSS. The study showed that cabergoline significantly lowered hematocrit, hemoglobin, and ascites on day 4 and 6 after treatment compared with placebo.

Ata et al. (2014) evaluated the use of cabergoline as a preventive strategy for OHSS with a varying dose from $0.25 \mathrm{mg}$ up to $1.0 \mathrm{mg}$ and showed a statistically significant reduction in the incidence of severe OHSS in the cabergoline group which agreed with our results. The studies used different regimens, and showed no statistical evidence of the timing of cabergoline administration (day of hCG injection versus after oocyte retrieval) on final oocyte maturation, fertilization rate or clinical outcome for the prevention of OHSS in high-risk patients. Both treatment modalities effectively decrease the incidence of severe OHSS.

Niyazi Kllıç (2015) showed a significant effect to reduce the risk of OHSS development. That assumed that $0.5 \mathrm{mg}$ of cabergoline could be safely and effectively reduce the incidence of OHSS.

\section{CONCLUSION}

Cabergoline reduced the incidence of OHSS in ICSI cycles. Women at high risk of OHSS; cabergoline can be administered as soon as the hCG injection to prevent early OHSS. Higher rates of clinical and chemical pregnancy were observed after cabergoline administration in ICSI cycles.

\section{REFERENCES}

1. Ata B, Seyhan A, Orhaner S and Urman B. (2014): High dose cabergoline in management of ovarian hyperstimulation syndrome. Fertil Steril., 92: 1168.

2. Busso C, Fernández-Sánchez M, GarcíaVelasco J, Landeras $\mathbf{J}$, Ballesteros $\mathrm{A}$, Muñoz E, González S, Simón C, Arce J and Pellicer A. (2010): The non-ergot derived dopamine agonist quinagolide in 
prevention of early ovarian hyperstimulation syndrome in IVF patients, Hum Reprod., 25(4): 995-1004.

3. Chen AA, Tan L, Suraj V, Reijo Pera $R$ and Shen S. (2013): Biomarkers identified with time-lapse imaging: discovery, validation, and practical application. Fertil Steril., 99(4):1035-1043.

4. Devroey $P$ and Adriaensen P. (2011): OHSS free clinic. Facts, views \& vision in ObGyn., 3(1):43-47.

5. El-Garhy I, Abdel Motaal A and Omr M. (2018): Comparison between Cabergoline andCoasting in Prevention of Ovarian Hyperstimulation Syndrome and their effect on Intracytoplasmic Sperm Injection Outcome The Egyptian Journal of Hospital Medicine, 73 (1): 5753-5769.

6. Gaafar S, El-Gezary D and El Maghraby HA. (2019): Early onset of cabergoline therapy for prophylaxis from ovarian hyperstimulation syndrome (OHSS): A potentially safer and more effective protocol., 19(2):145-148.

7. Ghaebi NK, Amirian M, Zarmehri B and Zabihi H. (2016): Comparison of the effect of letrozole versus cabergoline for prevention of ovarian hyperstimulation syndrome (OHSS) in patients under ovulation induction treatments and IVF cycles. Iranian Journal of Obstetrics, Gynecology and Infertility, 18(184):1-8.k.

8. Gómez R, Soares SR, Busso C, GarciaVelasco JA, Simón $C$ and Pellicer A. (2010): Physiology and pathology of ovarian hyperstimulation syndrome. Semin Reprod Med., 28(6):448-57.

9. Jellad S, Haj Hassine A, Basly M, Mrabet A, Chibani $M$ and Rachdi R. (2017): Vascular endothelial growth factor antagonist reduces the early onset and the severity of ovarian hyperstimulation syndrome. J Gynecol Obstet Hum Reprod., 46:87-91.

10. Kamel RA, Hanafy A, Omran E, Halwagy $A$ and Shaheen AH. (2016): Quinagolide compared with cabergoline in the prevention of ovarian hyperstimulation syndrome: a randomized trial. Evid Based Women Health J., 6(4):127-130.

11. Kılıç N, Özdemir Ö, Başar HC, Demircan F, Ekmez F and Yücel O. (2015): Cabergoline for preventing ovarian hyperstimulation syndrome in women at risk undergoingin vitro fertilization/ intracytoplasmic sperm injection treatment cycles: a randomized controlled study. Avicenna J Med., 5(4):123-127.

12. Leitao VM, Moroni RM, Seko LM, Nastri CO and Martins WP. (2014): Cabergoline for the prevention of ovarian hyperstimulation syndrome: Systematic review and meta-analysis of randomized controlled trials. Fertil Steril., 101:664-675.

13. Lo Monte G, Murisier F, Piva I, Germond $M$ and Marci R. (2013): Focus on intracytoplasmic morphologically selected sperm injection (IMSI): a mini-review. Asian J Androl., 15(5):608-615.

14. Mourad S, Brown $J$ and Farquhar $C$. (2017): Interventions for the prevention of OHSS in ART cycles: An overview of Cochrane reviews. CochraneDatabase Syst Rev., CD012103.

15. Seow KM, Lin YH, Bai CH, Chen HJ, Hsieh BC, Huang LW, Tzeng CR and Hwang JL. (2013): Clinical outcome according to timing of cabergoline initiation for prevention of OHSS: a randomized controlled trial. Reproductive Biomedicine Online, 26(6): 562-8.

16. Soares SR. (2012): Etiology of OHSS and use of dopamine agonists.Fertil. Steril., 97: 517-522.

17. Tang H, Hunter T, Hu Y, Zhai SD, Sheng $\mathbf{X}$ and Hart RJ.: Cabergoline for preventing ovarian hyperstimulation syndrome. Cochrane Database of Systematic Reviews, (2): 215-223.

18. Várnagy Á, Bódis J, Mánfai Z, Wilhelm F, Busznyák C and Koppán M. (2010): Lowdose aspirin therapy to prevent ovarian hyperstimulation syndrome. Fertility and Sterility, 93(7):2281-4. 
تأثير عقار الكابرجولين كمحاكى للدوبامين على انغماس إنه إنها

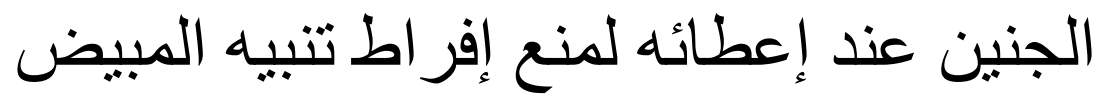

مروة شوقي مصطفى الجندى، يحيى عبد السـلام وفا، هشــام فكرى أبو سنـهـ إله قسم أمراض النساء و التوليد، كلية الطب (بنين)، جامعة الأزهر

E-mail: dr.marwashawky@gmail.com

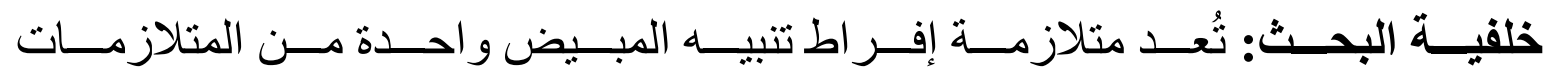

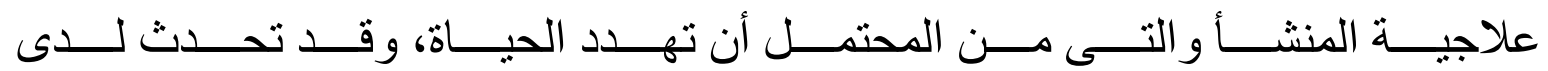
السيدات الأصحاء فى سن الإنجاب ممن يخضعن لتحفيز المبيض.

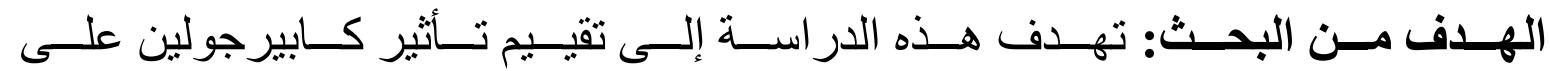
الزرع عند استخدامه لنع أو علاج متلازمة فرط التنشيط المبيضي.

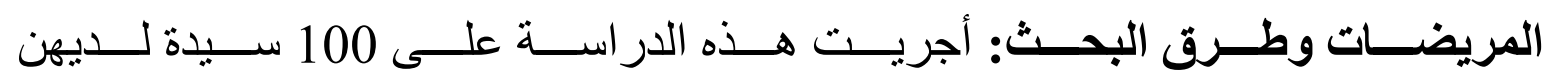

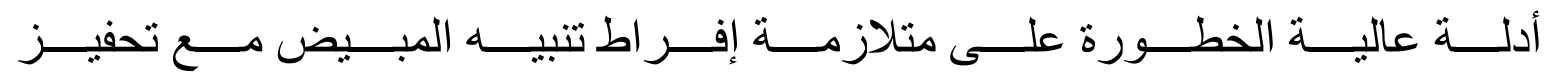

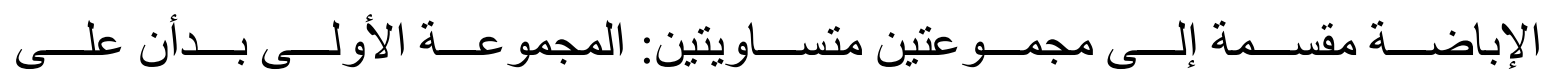

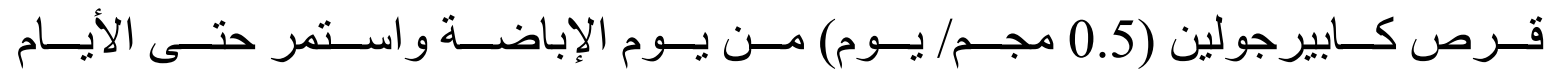

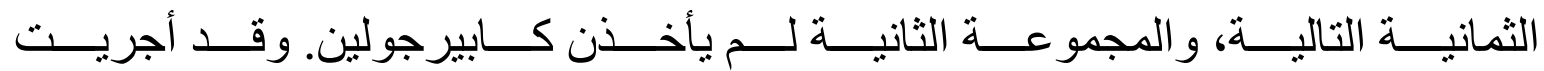

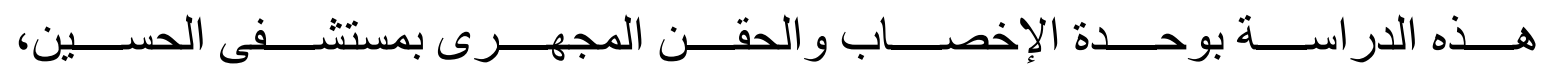

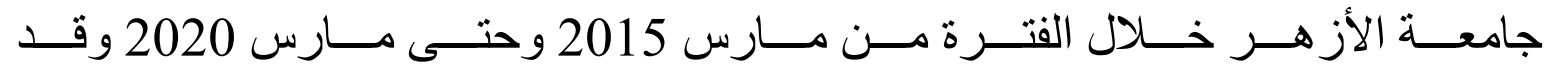

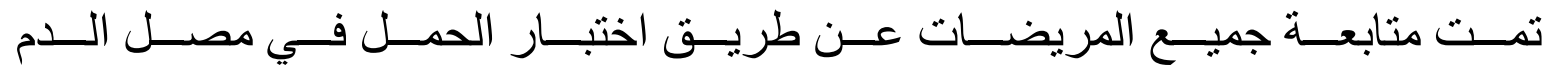

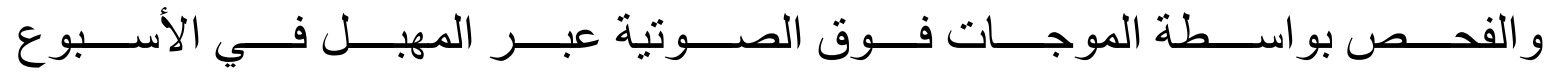

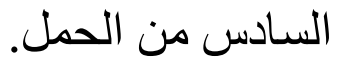

نتــائج البحــث: أظهــرت الدراســـة وجــود اختلافــات ذات دلالـــة إحصــائية بــين

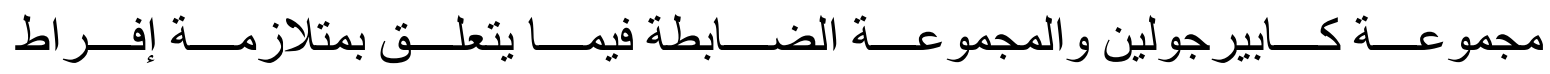




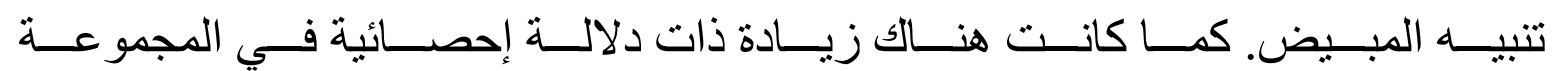
الموجبة الأولى مقارنةً بالمجمو عة الثانية فيما يتعلق بنبض قلب زلب الجنين.

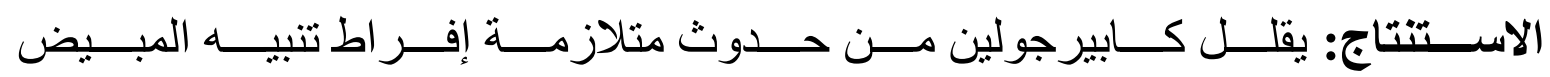

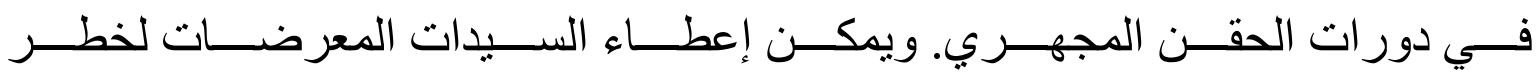

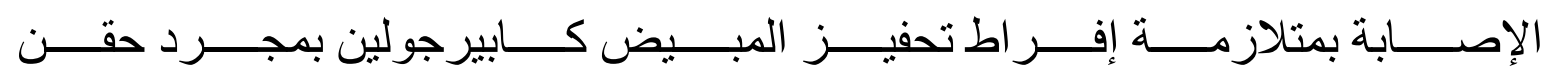

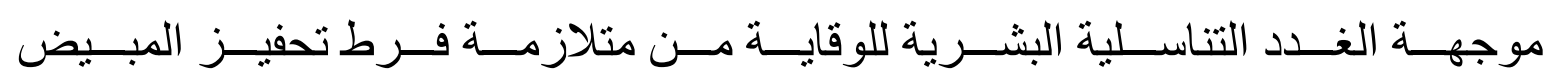

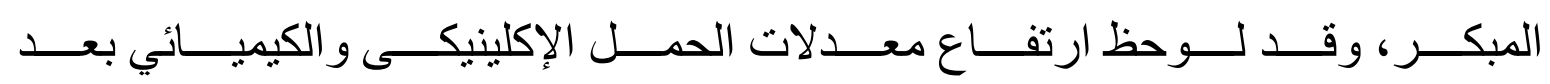
إعطاء كابيرجولين في دورات الحقن المجهري. الكلمات الدالة: كابيرجولين، زرع الجنين، إفر اط تنبيه المبيض. 